\title{
KINERJA DIREKTORAT PELAYANAN USAHA PENANGKAPAN IKAN-KKP SEBAGAI SALAH SATU STAKEHOLDER PERIZINAN USAHA PENANGKAPAN IKAN
}

\author{
Performance of Directorate Fishing Business-MMAF as One of The Fisheries \\ Business License Stakeholders
}

Oleh:

\author{
Shinta Yuniarta ${ }^{*}$, Sugeng H. Wisudo ${ }^{2}$, Budhi H. Iskandar ${ }^{2}$ \\ ${ }^{1}$ Lembaga Pengembangan Perikanan Laut (LP2L) \\ 2 Departemen Pemanfaatan Sumber Daya Perikanan, FPIK, IPB \\ *Korespondensi: syuniarta@yahoo.com
}

Diterima: 26 Desember 2011; Disetujui: 5 Maret 2011

\begin{abstract}
Licensing process of fisheries business is conducted on Directorate Fishing Business Service - Ministry of Marine Affair and Fisheries (MMAF), which is the main actor of fisheries business license (Yuniarta 2009). Several constraints of licensing process are found in this research. There are lateness of licensing process in some regions, minimum research development of licensing process and duration of each stage and over all of the stage of licensing process, so that required performance measurement of the directorate. The purpose of this research is measuring performance of Directorate Fishing Business Service based on balanced scorecard approach, that assess on four perspectives, there are learn and growth, business internal process, financial and customer. The result of these perspectives on Directorate Fishing Business Service performance is 3.34, therefore the directorate needs a strategy to increase the performance.
\end{abstract}

Key words: fisheries business, license process, performance, balanced scorecard.

\begin{abstract}
ABTRAK
Proses perizinan usaha perikanan dilaksanakan di Direktorat Pelayanan Usaha Penangkapan Ikan - Kementerian Kelautan dan Perikanan (KKP), yang merupakan aktor utama dalam perizinan usaha penangkapan ikan (Yuniarta 2009). Beberapa kendala pada proses perizinan ditemukan dalam penelitian ini. Yaitu proses perizinan di daerah yang kadang terlambat dilakukan, minimnya pengembangan proses perizinan melalui penelitian atau kajian, kejelasan proses waktu tiap tahapan dan lamanya waktu yang dibutuhkan untuk penerbitan izin, sehingga dibutuhkan pengukuran kinerja pada direktorat ini. Tujuan penelitian ini adalah mengukur kinerja Direktorat Pelayanan Usaha Penangkapan ikan berdasarkan pendekatan balanced scorecard, yang menilai berdasarkan empat perspektif, yaitu perspektif pembelajaran dan pertumbuhan, proses bisnis internal, finansial dan pelanggan. Nilai hasil analisis keseluruhan empat perspektif pada kinerja Direktorat Pelayanan Usaha Penangkapan Ikan adalah 3,34, untuk itu perlu suatu strategi untuk meningkatkan kinerja direktorat ini.
\end{abstract}

Kata kunci: usaha perikanan, proses perizinan, kinerja, balanced scorecard 


\section{PENDAHULUAN}

Penurunan produktivitas perikanan di sebagian wilayah perairan mendorong kegiatan pengelolaan sumber daya perikanan untuk mewujudkan kondisi perikanan yang berkelanjutan. Berbagai tindakan pengelolaan sumber daya perikanan telah dilakukan pemerintah dengan melakukan berbagai kebijakan seperti perizinan dan kuota penangkapan, konservasi kawasan perairan, kerjasama pemerintah pusat dengan pemerintah daerah dengan menggunakan instrumen legalitas untuk para pelaku kegiatan penangkapan ikan. Gil et al. (1996) menyebutkan 3 bentuk regulasi yang dilakukan oleh regulator untuk pengelolaan sumber daya perikanan adalah alokasi properti, kontrol pajak dan perizinan dengan kuota. Pemerintah Indonesia sebagai regulator pengelolaan sumberdaya perikanan menggunakan regulasi perizinan untuk mengatur kegiatan penangkapan ikan dan mengelola sumber daya ikan melalui Kementerian Kelautan dan Perikanan (KKP) dalam Peraturan Menteri Kelautan dan Perikanan. Inti dari penerapan perizinan adalah menginternalisasikan biaya (fishing fee) kedalam usaha penangkapan ikan (Mulyana 2007), dimana hak penangkapan diberikan kepada penangkap ikan setelah melakukan perizinan di pemerintah pusat atau di daerah.

Undang-undang RI Nomor 31 tahun 2004 tentang perikanan menyebutkan bahwa perusahaan perikanan harus memiliki surat izin usaha perikanan yang disebut dengan SIUP. Pada kegiatan penangkapan, pengoperasian kapal penangkap ikan di wilayah pengelolaan perikanan Republik Indonesia wajib memiliki surat izin penangkapan ikan (SIPI), sedangkan pengoperasian kapal pengangkut ikan di wilayah pengelolaan perikanan Republik Indonesia wajib memiliki surat izin kapal pengangkut ikan (SIKPI). Kewenangan penerbitan dan/atau memperpanjang izin diberikan oleh Menteri Kelautan dan Perikanan kepada Direktur Jenderal Perikanan Tangkap. Kewenangan tersebut juga dibagi kepada pemerintah provinsi untuk perizinan kapal perikanan berukuran 15-30 GT, kepada pemerintah kabupaten untuk perizinan kapal perikanan berukuran <15 GT, sedangkan proses perizinan kapal perikanan berukuran $>30$ GT dilakukan pada Direktorat Pelayanan Usaha Penangkapan Ikan-KKP. Proses perizinan dilakukan di Direktorat Pelayanan Usaha Penangkapan Ikan. Hasil penelitian Yuniarta (2009) menunjukkan bahwa KKP khususnya Direktorat Pelayanan Usaha Penangkapan Ikan merupakan aktor utama dalam proses perizinan usaha penangkapan ikan. Beberapa contoh kendala yang ditemukan dalam proses perizinan usaha penangkapan ikan adalah proses per- izinan di daerah yang kadang terlambat dilakukan, minimnya pengembangan proses perizinan melalui penelitian atau kajian dengan melibatkan pelaku usaha perikanan, kejelasan proses waktu tiap tahapan dan lamanya waktu yang dibutuhkan untuk penerbitan izin. Berdasarkan hal tersebut, maka perlu dilakukan pengukuran kinerja Direktorat Pelayanan Usaha Penangkapan lkan-KKP.

Penelitian ini bertujuan melakukan pengukuran kinerja Direktorat Pelayanan Usaha Penangkapan Ikan dengan pendekatan metode balanced scorecard. Pengukuran kinerja didefinisikan sebagai proses evaluasi sebaik apa organisasi dikelola dan nilai yang sampai kepada konsumen dan stakeholder lain (Moullin 2002 diacu dalam Moullin 2009). Pengukuran kinerja dengan pendekatan balanced scorecard menilai berdasarkan 4 perspektif yaitu perspektif pembelajaran dan pertumbuhan, perspektif proses bisnis internal, perspektif finansial dan perspektif pelanggan (Kaplan 2000, Gaspersz 2002, Niven 2003). Beberapa penelitian menggunakan balanced scorecard sebagai pengukuran kinerja dan strategi telah dilakukan pada lembaga non profit maupun institusi pemerintah (Moullin 2009;Wing et al. 2007; Wu et al. 2011).

\section{METODOLOGI}

Pada penelitian ini penilaian kinerja menggunakan pendekatan metode balanced scorecard untuk lembaga non profit (Niven 2003). Penilaian dan evaluasi yang dilakukan berdasarkan kondisi yang sudah berjalan menggunakan 4 perspektif yaitu pembelajaran dan pertumbuhan, proses bisnis internal, finansial dan pelanggan. Masing-masing indikatornya dibuat dalam suatu struktur penilaian dimana variabelnya adalah faktor penggerak, performa dan dampak (Koellner et al. 2008) dari perizinan usaha penangkapan ikan. Faktor penggerak Direktorat Pelayanan Usaha Penangkapan Ikan adalah tujuan atau visi yaitu "Pelayanan Prima Perizinan Usaha Perikanan Tangkap di Pusat dan Daerah". Kompetensi staf, penyerapan dana dan upaya riset pengembangan dapat menjadi indikator kunci implementasi visi. Ketiga indikator tersebut untuk mencapai inovasi proses perizinan. Kompetensi staf adalah indikator untuk mencapai partisipasi staf dalam proses perizinan. Partisipasi staf dan inovasi untuk mencapai operasi produksi/perizinan di Direktorat Pelayanan Usaha Penangkapan Ikan. Operasi produksi tersebut memberikan dampak adanya PNBP, kepuasan pelanggan dan purna izin yang menentukan izin dicabut atau dilanjutkan. Metode penelitian, jenis data dan analisis yang digunakan pada masing-masing perspektif disajikan pada Tabel 1. 


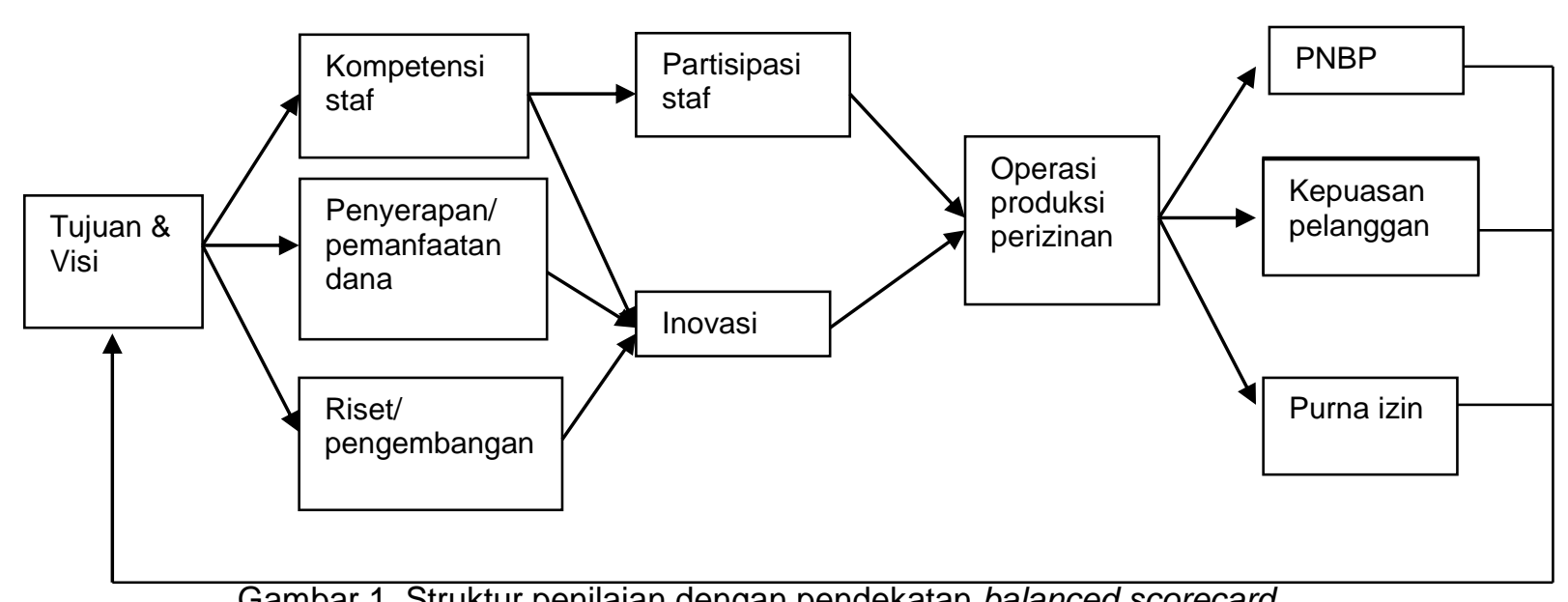

Gambar 1 Struktur penilaian dengan pendekatan balanced scorecard.

Tabel 1 Metode penelitian, jenis data dan analisis data masing-masing perspektif.

\begin{tabular}{|c|c|c|c|c|}
\hline No & Perspektif & Metode penelitian & Jenis data & Analisis data \\
\hline 1 & $\begin{array}{l}\text { Pembelajaran dan } \\
\text { pertumbuhan }\end{array}$ & Kuesioner & Primer & $\begin{array}{l}\text { Persentase tingkat } \\
\text { kepuasan staf }\end{array}$ \\
\hline 2 & Proses bisnis internal & $\begin{array}{l}\text { Kajian pustaka, survei } \\
\text { dan wawancara }\end{array}$ & $\begin{array}{l}\text { Primer dan } \\
\text { Sekunder }\end{array}$ & - \\
\hline 3 & Finansial & $\begin{array}{l}\text { Kajian pustaka dan } \\
\text { survei }\end{array}$ & Sekunder & $\begin{array}{l}\text { Persentase realisasi } \\
\text { pencapaian }\end{array}$ \\
\hline 4 & Pelanggan & $\begin{array}{l}\text { Kuesioner dan } \\
\text { wawancara }\end{array}$ & Primer & $\begin{array}{l}\text { Analisis tingkat } \\
\text { kepuasan pelanggan }\end{array}$ \\
\hline
\end{tabular}

Pada kuesioner terdiri dari 5 kategori jawaban yang masing-masing memiliki bobot skor tersendiri dengan menggunakan pengembangan skala Likert, yaitu skor terendah berada pada pilihan jawaban 1 dan skor tertinggi berada pada pilihan jawaban 5. Penentuan skor berdasarkan pengembangan skala nilai pencapaian kinerja dari rujukan pada Buku Pedoman Penyusunan LAKIP-Modul Pengukuran Kinerja yang diterbitkan Lembaga Administrasi Negara (LAN) Republik Indonesia dan Badan Pengawasan Keuangan dan Pembangunan (BPKP) dan pengembangan harapan pelanggan berdasarkan hasil wawancara (Tabel 2).

Direktorat Pelayanan Usaha Penangkapan Ikan-KKP mempunyai tugas melaksanakan penyiapan perumusan kebijakan, standar, norma, pedoman, kriteria, prosedur dan bimbingan teknis di bidang pelayanan usaha penangkapan ikan (Peraturan Menteri Kelautan dan Perikanan Nomor PER.07/MEN/2005 tentang Organisasi dan Tata Kerja Departemen Kelautan dan Perikanan tanggal 24 Juni 2005), berdasarkan hal tersebut, maka Direktorat Pelayanan Usaha Penangkapan Ikan harus berfokus pada pelayanan terhadap pelaku usaha penangkapan (public service) dengan mempertimbangkan perikanan yang bertanggung jawab. Pada hasil analisis kinerja secara keseluruhan masing-ma- sing perspektif diberikan bobot. Pembobotan pada analisis kinerja keseluruhan berbeda-beda pada tiap aplikasi balanced scorecard, tergantung pada kebutuhan masing-masing organisasi.

Pada organisasi profit bobot terbesar diberikan pada perspektif finansial, sedangkan pada Direktorat Pelayanan Usaha Penangkapan Ikan yang merupakan organisasi non profit atau pemerintah, bobot terbesar diberikan pada perspektif yang bersentuhan langsung dengan pelaku usaha, yaitu perspektif pelanggan dan perspektif proses bisnis internal diberikan bobot masing-masing $30 \%$, dan perspektif pembelajaran pertumbuhan dan perspektif finansial dimana tidak bersentuhan langsung dengan pelaku usaha diberikan bobot masing-masing $20 \%$. Bobot dibagi pada masing-masing indikator. Pada perspektif pertumbuhan dan pembelajaran, pembagian bobot pada indikator riset atau pengembangan proses perizinan usaha perikanan mendapat bobot lebih kecil dibanding indikator lain, dikarenakan Direktorat Pelayanan Usaha Penangkapan Ikan bukanlah direktorat teknis untuk melakukan riset atau pengembangan proses perizinan. Pada analisis hasil kinerja secara keseluruhan, nilai merupakan hasil perkalian skor dan bobot, deskripsi nilai dijelaskan pada Tabel 3. 
Tabel 2 Deskripsi skor menggunakan skala Likert.

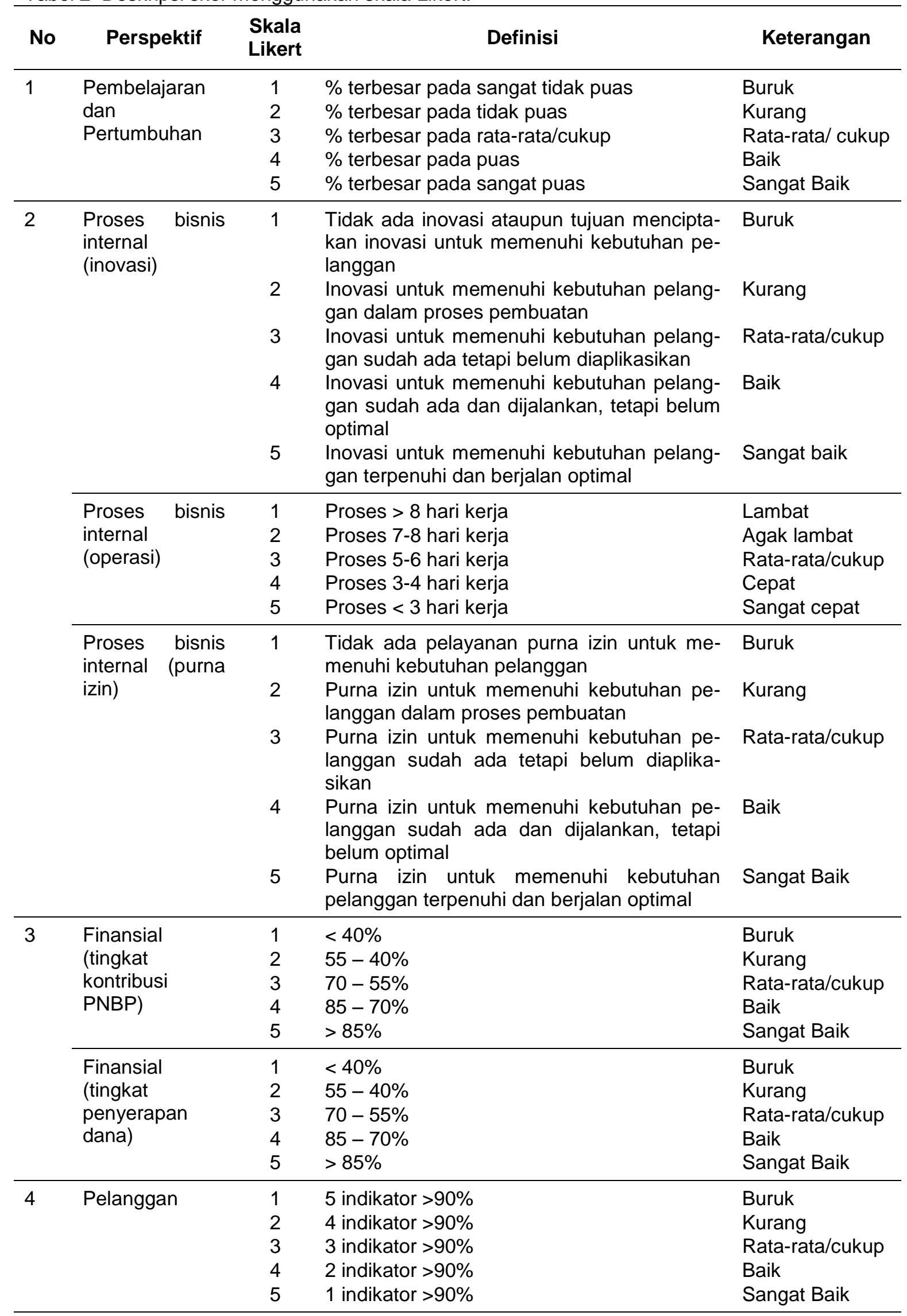


Tabel 3 Deskripsi pada analisis hasil kinerja keseluruhan.

\begin{tabular}{cccccc}
\hline Nilai & $\mathbf{1}$ & $\mathbf{2}$ & $\mathbf{3}$ & $\mathbf{4}$ & $\mathbf{5}$ \\
\hline Deskripsi & Buruk & Kurang & Cukup/Rata-rata & Baik & Sangat Baik \\
\hline
\end{tabular}

Tabel 4 Indikator pengukuran pada perspektif pembelajaran dan pertumbuhan.

\begin{tabular}{|c|c|c|c|c|c|}
\hline \multirow{2}{*}{ Uraian } & \multicolumn{5}{|c|}{ Jawaban responden (responden) (\%) } \\
\hline & $\begin{array}{l}\text { Sangat } \\
\text { tidak } \\
\text { puas }\end{array}$ & $\begin{array}{l}\text { Tidak } \\
\text { puas }\end{array}$ & $\begin{array}{l}\text { Rata- } \\
\text { rata/ } \\
\text { cukup }\end{array}$ & Puas & $\begin{array}{c}\text { Sangat } \\
\text { puas }\end{array}$ \\
\hline \multicolumn{6}{|l|}{$\begin{array}{c}\text { Indikator pengukuran tingkat kompetensi } \\
\text { staf }\end{array}$} \\
\hline \multirow{2}{*}{$\begin{array}{l}\text { Kesempatan mengikuti pelatihan yang berkait- } \\
\text { an dengan perizinan }\end{array}$} & 0 & 1 & 9 & 30 & 12 \\
\hline & $0 \%$ & $1,92 \%$ & $17,3 \%$ & $57,7 \%$ & $23,1 \%$ \\
\hline \multirow{2}{*}{$\begin{array}{l}\text { Kesempatan melakukan pekerjaan menggu- } \\
\text { nakan kemampuan yang dimiliki }\end{array}$} & 0 & 2 & 6 & 31 & 13 \\
\hline & $0 \%$ & $3,85 \%$ & $11,5 \%$ & $59,6 \%$ & $25,0 \%$ \\
\hline Rata-rata (\%) & $0 \%$ & $2,89 \%$ & $14,40 \%$ & $58,65 \%$ & $24,05 \%$ \\
\hline \multicolumn{6}{|l|}{ Indikator pengukuran partisipasi staf } \\
\hline \multirow[t]{2}{*}{ Kesempatan bekerja sama dengan teman } & 0 & 0 & 5 & 34 & 13 \\
\hline & $\begin{array}{c}0 \% \\
0\end{array}$ & $\begin{array}{c}0 \% \\
0\end{array}$ & $\begin{array}{c}9,62 \% \\
3\end{array}$ & $\begin{array}{c}65,4 \% \\
40\end{array}$ & $\begin{array}{c}25 \% \\
9\end{array}$ \\
\hline \multirow{5}{*}{$\begin{array}{l}\text { Kesempatan menjadi bagian penting dalam } \\
\text { kelompok kerja } \\
\text { Jumlah teman yang terlibat dalam setiap pro- } \\
\text { ses perizinan } \\
\text { Kesibukan sepanjang waktu kerja }\end{array}$} & $0 \%$ & $0 \%$ & $5,77 \%$ & $76,9 \%$ & $17,3 \%$ \\
\hline & 0 & 0 & 3 & & 12 \\
\hline & $0 \%$ & $0 \%$ & $5,77 \%$ & $71,2 \%$ & $23,1 \%$ \\
\hline & 0 & 0 & 14 & 25 & 13 \\
\hline & $0 \%$ & $0 \%$ & $26,9 \%$ & $48,1 \%$ & $25 \%$ \\
\hline \multirow{6}{*}{$\begin{array}{l}\text { Kesempatan bekerja sendiri menyelesaikan } \\
\text { pekerjaan } \\
\text { Kesempatan menjadi bagian penting dalam } \\
\text { kelompok kerja } \\
\text { Kesempatan mengembangkan karir }\end{array}$} & 0 & 0 & & & \\
\hline & $0 \%$ & $0 \%$ & $11,5 \%$ & $69,2 \%$ & $19,2 \%$ \\
\hline & 0 & 0 & 3 & 43 & 6 \\
\hline & $0 \%$ & $0 \%$ & $5,77 \%$ & $82,7 \%$ & $11,5 \%$ \\
\hline & 0 & 0 & 17 & & 7 \\
\hline & $0 \%$ & $0 \%$ & $32,7 \%$ & $53,8 \%$ & $13,5 \%$ \\
\hline \multirow{2}{*}{$\begin{array}{c}\text { Rata-rata }(\%) \\
\begin{array}{c}\text { Indikator pengukuran riset dan } \\
\text { pengembangan proses perizinan usaha } \\
\text { penangkapan ikan }\end{array}\end{array}$} & $0 \%$ & $0 \%$ & $14,00 \%$ & $66,76 \%$ & $19,23 \%$ \\
\hline & & & & & \\
\hline \multirow{2}{*}{$\begin{array}{l}\text { Kesempatan melakukan penelitian yang ber- } \\
\text { kaitan dengan perizinan usaha penangkapan } \\
\text { ikan }\end{array}$} & 0 & 1 & 27 & 15 & 9 \\
\hline & $0 \%$ & $1,92 \%$ & $51,9 \%$ & $28,8 \%$ & $17,3 \%$ \\
\hline \multirow{2}{*}{$\begin{array}{l}\text { Jumlah penelitian yang berkaitan dengan pro- } \\
\text { ses perizinan usaha penangkapan ikan }\end{array}$} & 0 & 4 & 32 & 14 & 2 \\
\hline & $0 \%$ & $7,69 \%$ & $61,5 \%$ & $26,9 \%$ & $3,85 \%$ \\
\hline Rata-rata (\%) & $0 \%$ & $4,81 \%$ & $56,70 \%$ & $27,85 \%$ & $10,58 \%$ \\
\hline
\end{tabular}

\section{HASIL DAN PEMBAHASAN}

Perspektif pembelajaran dan pertumbuhan

Tolak ukur yang digunakan pada perspektif ini adalah kompetensi staf, partisipasi staf dan riset atau pengembangan proses perizinan usaha perikanan.

Jumlah staf pada Direktorat Pelayanan Usaha Penangkapan Ikan-KKP yang terkait dengan proses perizinan sebanyak 53 orang yang terdiri dari 20 orang lulusan bidang perikanan 
dan sisanya adalah non perikanan (manajemen, teknik, dan administrasi) yang menunjang proses pelayanan perizinan usaha penangkapan ikan. Direktorat Pelayanan Usaha Penangkapan Ikan rutin melakukan kegiatan peningkatan sumberdaya manusia perizinan usaha perikanan tangkap. Kegiatan ini mulai dilaksanakan pada tahun 2003 dan rutin dilaksanakan tiap tahunnya. Pelatihan ditujukan bagi staf perizinan pusat yang ada di Direktorat Pelayanan Usaha Penangkapan Ikan maupun yang ada di daerah. Beberapa yang memberikan respon tidak puas pada uraian kesempatan mengikuti pelatihan yang berkaitan dengan perizinan $(1,92 \%$ responden) dikarenakan penunjukan pimpinan pada staf yang mengikuti pelatihan dengan pertimbangan-pertimbangan yang tidak diungkapkan secara transparan kepada staf lainnya. Hal lain yang berkaitan dengan pelatihan tersebut bahwa dalam pelaksanaannya seharusnya Direktorat melakukan komunikasi dengan pusat pelatihan KKP, sehingga kebutuhan-kebutuhan kompetensi yang dianggap perlu pada Direktorat Pelayanan Usaha Penangkapan Ikan dapat terakomodasi baik. $\mathrm{Pa}$ da uraian kesempatan melakukan pekerjaan menggunakan kemampuan yang dimiliki terdapat $3,85 \%$ responden menyatakan tidak puas dikarenakan penempatan staf pada posisi yang ditetapkan tidak diungkapkan berdasarkan kompetensi yang dimiliki staf tersebut. Berdasarkan uraian di atas maka pada indikator pengukuran tingkat kompetensi staf permasalahan pada transparansi pimpinan dalam penunjukkan staf mengikuti pelatihan dan penetapan posisi pekerjaan dalam proses perizinan. Kendala lain pada indikator ini adalah belum adanya koordinasi Direktorat Pelayanan Usaha Penangkapan Ikan dengan pusat pelatihan KKP untuk mengakomodasi kompetensi yang perlu ditingkatkan.

Pada indikator pengukuran partisipasi staf, tidak ditemukan responden yang menyatakan tidak puas. Hal ini menunjukkan bahwa partisipasi staf dalam proses perizinan telah berjalan dan terakomodasi dengan baik untuk menjadi bagian dalam kelompok kerja. Indikator pengukuran kesempatan melakukan penelitian yang berkaitan dengan perizinan dan indikator jumlah penelitian yang berkaitan dengan proses perizinan hanya sebagian kecil yang merasakan tidak puas, hal ini dibuktikan dari jumlah penelitian yang dilakukan KKP dalam rangka proses perizinan usaha perikanan masih belum dilakukan. Hasil penelitian yang terkait adalah perhitungan produktivitas kapal kaitannya dengan pungutan pada kapal-kapal ikan yang beroperasi yang merupakan hasil kajian Direktorat Kapal dan Alat Penangkap Ikan KKP. Sedangkan bagi staf yang merasakan cukup puas, puas dan sangat puas memiliki alasan bahwa Direktorat Pelayanan Usaha Penangkapan Ikan bukanlah direktorat teknis yang melakukan penelitian, sehingga masih dikatakan wajar bila direktorat ini memiliki jumlah penelitian sedikit yang berkaitan dengan proses perizinan itu sendiri.

\section{Perspektif proses bisnis internal}

Pengukuran pada perspektif ini yaitu tahap inovasi, tahap operasi/produksi dan tahap pelayanan purna izin. Pada tahap inovasi dilakukan identifikasi kebutuhan para pelanggan dimasa kini dan masa mendatang serta merumuskan cara untuk memenuhi keinginan dan kebutuhan tersebut. Direktorat Pelayanan Usaha Penangkapan Ikan dalam melakukan proses perizinan berdasarkan pada Peraturan Menteri Kelautan dan Perikanan. Pada tahun 2006, proses perizinan dilakukan berdasarkan Peraturan Menteri Nomor PER.17/MEN/2006, direvisi menjadi Peraturan Menteri Nomor PER.05/ MEN/2008 dan perubahannya pada tahun 2009 yaitu Peraturan Menteri Nomor PER.12/MEN/ 2009.

Berdasarkan penunjukkan dari Menteri Kelautan dan Perikanan, maka KKP menerbitkan izin tersebut. Bagi pengusaha yang berlokasi di sekitar atau dekat dengan Jakarta, maka pengajuan izin dapat dilakukan di KKP pusat yang berlokasi di Jl. Medan Merdeka Timur No.16 It. 9 Jakarta Pusat, sedangkan bagi pengusaha yang berlokasi di luar daerah, Direktorat Pelayanan Usaha Penangkapan Ikan memiliki program perbantuan proses pelayanan perizinan pusat di daerah yang dilaksanakan rutin setiap tahun. Hingga saat ini sudah dilaksanakan di 7 Dinas Propinsi meliputi NAD, Kepri, Jateng, Jatim, Bali, Sulut, Papua, serta 14 UPT Pelabuhan Perikanan yaitu PPS. Belawan, Cilacap, Bitung, Kendari, Bungus, PPN. Sibolga, Pekalongan, Ambon, Tj. Pandan, Kejawanan, Prigi, Pemangkat, Tual dan PPP Sorong. Program perbantuan tersebut mengatasi kebutuhan para pelaku usaha untuk melakuan pengajuan izin bagi yang ada di daerah. Inovasi lain dari Direktorat Pelayanan Usaha Penangkapan Ikan untuk memenuhi kebutuhan pelaku usaha adalah saat izin diperoleh (purna izin) dimana akses pelaporan LKU (Laporan Kegiatan Usaha) dan LKP (Laporan Kegiatan Penangkapan Ikan dan Pengangkutan/Pengumpulan Ikan) dilakukan berbasis web.

Pada dasarnya pembuatan peraturan/ regulasi pemerintah terhadap izin usaha perikanan merupakan sarana untuk mengakomodasi kebutuhan para pengusaha dalam mengeksploitasi sumberdaya ikan di perairan Indonesia dengan manajemen atau pengelolaan 
yang bertanggung jawab. Perubahan-perubahannya terus dilakukan untuk mendapatkan kondisi ideal/optimum di suatu perairan. Desain sistem hak penangkapan yang pernah dilakukan tidak ada satupun yang dapat disebut sangat efektif dalam melestarikan dan melaksanakan eksploitasi stok perikanan yang efisien dan adil (Young 1999). Apabila target yang diinginkan sulit dicapai, merupakan suatu indikasi bahwa persyaratan regulasi perlu direvisi (Karahalios et al. 2010).

Aspek selanjutnya dalam pengukuran kinerja proses bisnis internal Direktorat Pelayanan Usaha Penangkapan Ikan adalah kemampuan operasinya. Pada tahap kemampuan operasi dilakukan identifikasi terhadap lamanya proses penyelesaian perizinan untuk mendapatkan izin dari Direktorat Pelayanan Usaha Penangkapan Ikan. Terhitung mulai pengajuan dilakukan, waktu proses penyelesaian perizinan paling lama mencapai hingga 14 hari kerja hingga surat izin diperoleh pemohon dengan asumsi bahwa kelengkapan dokumen tidak ada yang kurang. Dalam proses tersebut KKP melakukan cek fisik pada kapal yang dilakukan oleh Direktorat Kapal dan Alat Penangkap IkanKKP. Selanjutnya setelah pemeriksaan cek fisik kapal, proses perizinan diteruskan ke Direktorat Pelayanan Usaha Penangkapan Ikan. Pada Direktorat Pelayanan Usaha Penangkapan Ikan, proses hanya berjalan kurang dari 1 minggu yaitu selama 3-4 hari kerja dengan asumsi persyaratan sesuai Peraturan Menteri No. PER/12/MEN/2009 telah dipenuhi. Berdasarkan hasil wawancara dengan pelanggan, proses penyelesaian perizinan tidak memiliki tenggat waktu yang tetap pada masing-masing tahap maupun proses perizinan secara keseluruhan, sedangkan pelanggan membutuhkan waktu yang singkat supaya kapal dapat kembali beroperasi dan melakukan kegiatan penangkapan ikan. Direktorat Pelayanan Usaha Penangkapan Ikan juga belum menetapkan batas waktu penyelesaian proses perizinan baik pada masing-masing tahap maupun proses secara keseluruhan, sehingga dibutuhkan suatu pengelolaan supaya kefektifan operasi dan kendali pro- ses dalam proses perizinan dapat terukur. Untuk itu, Direktorat Pelayanan Usaha Penangkapan Ikan dapat mengaplikasikan Sistem Manajemen Mutu ISO 9001:2008 untuk meningkatkan performa mutu pelayanan perizinan usaha penangkapan ikan. Beberapa usaha perikanan yang berbasis di daerah menjadi salah satu kendala dalam proses operasi, dimana proses perizinan di Direktorat Pelayanan Usaha Penangkapan Ikan belum dapat dilakukan secara online dengan melibatkan staf di Dinas Kelautan dan Perikanan di daerah. Pengembangan e-service dapat menjadi salah satu target bagi Direktorat Pelayanan Usaha Penangkapan Ikan ke depannya yang dibarengi dengan pengawasan ketat dan kerjasama dengan Dinas Kelautan dan Perikanan di daerah. Perkembangan jumlah izin usaha dan izin kapal perikanan pada tahun 2004 sampai tahun 2008 ditampilkan pada Tabel 5.

Aspek terakhir pada perspektif proses bisnis internal adalah pelayanan setelah izin didapat. Setelah izin didapat bagi para pemegang izin maka kegiatan usaha dan penangkapan mulai dilaksanakan. Pada purna pelayanan perizinan di peroleh, pemegang izin diwajibkan untuk melaporkan hasil kegiatan penangkapan ikan, untuk itu Direktorat Pelayanan Usaha Penangkapan Ikan memberikan sarana melalui website www.perizinan.dkp.go.id memberikan kemudahan akses pelaporan LKU (Laporan Kegiatan Usaha) dan LKP (Laporan Kegiatan Penangkapan Ikan dan Pengangkutan/ Pengumpulan Ikan), dimana komputer yang digunakan harus dilakukan instalasi aplikasi yang terdiri dari Dot Net Framework versi 1.1 dan Microsoft Data Access Component versi 2.7. Pada website tersebut juga dapat diunduh Petunjuk Penggunaan Sistem Aplikasi Pelaporan Kegiatan Usaha Perikanan Tangkap dalam bentuk Pdf. Saat ini sistem pelaporan yang dibuat oleh Direktorat Pelayanan Usaha Penangkapan Ikan berbasis web, pada tahun 2007 sudah dilakukan instal di 9 Pelabuhan yaitu Bungus, Ternate, Kendari, Pemangkat, Kejawanan, Ambon, Bitung, Sibolga dan Pekalongan, akan tetapi

Tabel 5 Jumlah izin usaha perikanan dan izin operasional kapal.

\begin{tabular}{llllll}
\hline & 2004 & 2005 & 2006 & 2007 & 2008 \\
\hline Izin usaha & 2.212 & 2.450 & 2.604 & 2.631 & 2.505 \\
Izin operasional kapal & 6.259 & 6.852 & 6.962 & 6.803 & 6.269 \\
\hline
\end{tabular}

Sumber : Direktorat Pelayanan Usaha Penangkapan ikan, DKP (2009)

Tabel 6 Jumlah izin kumulatif kapal ikan Indonesia yang dicabut.

\begin{tabular}{cccccc}
\hline Tahun & 2004 & 2005 & 2006 & 2007 & 2008 \\
\hline Jumlah izin kapal dicabut & 152 & 102 & 174 & 339 & 1.015 \\
\hline Sumber : Direktorat Pelayanan Usaha Penangkapan Ikan, DKP (Maret 2009) & &
\end{tabular}


sistem pelaporan ini belum berjalan dengan optimal. Pelayanan puna izin lainnya adalah pencabutan izin yang sudah kadaluarsa baik pada kapal penangkap maupun pengangkut. Jumlah izin kumulatif kapal ikan Indonesia yang dicabut disajikan pada Tabel 6 . Pelayanan purna izin yang dilakukan oleh Direktorat Pelayanan Usaha Penangkapan Ikan bertujuan untuk memenuhi kebutuhan pengguna izin dalam melaporkan kegiatan usahanya dan menjaga kelestarian sumber daya perikanan. Kondisi ini untuk menjaga kuota tangkap pada tiap wilayah pengelolaan perikanan (WPP) yang berubah tiap tahunnya dimana KKP menjadi regulator terhadap pengelolaan perikanan yang bertanggung jawab. Izin SIPI dan SIKPI dapat dicabut jika :

1) Pelanggaran: dapat berupa rekomendasi Ditjen P2SDKP, putusan pengadilan, rekomendasi POLRI, pemalsuan dokumen, rekomendasi AL atau masuk daftar IUU Fishing.

2) Permintaan pengusaha: kebakaran, tenggelam, kapal dijual, rugi operasi, kapal rusak atau izin dikembalikan

3) Tertib administrasi: tidak menyampaikan laporan LKU/LKP, atau masa berlaku telah habis.

\section{Perspektif Finansial}

Direktorat Pelayanan Usaha Penangkapan Ikan merupakan suatu instansi pemerintah yang berorientasi pada pelayanan bukan pada profit atau keuntungan. Indikator perspektif finansial diukur berdasarkan pemasukan dan pengeluaran pada Direktorat Pelayanan Usaha Penangkapan Ikan. Pemasukan yang dimaksud adalah nilai PNBP berdasarkan Surat Perintah Pembayaran (SPP) Pungutan Pengusahaan Perikanan (PPP) maupun Pungutan Hasil Perikanan (PHP) pada tahun 2005-2008. Sedangkan pengeluaran yang dimaksud adalah jumlah pencapaian kegiatan Direktorat Pelayanan Usaha Penangkapan Ikan-KKP.
Sumber keuangan Direktorat Pelayanan Usaha Penangkapan Ikan berasal dari APBN yang diberikan melalui KKP, Direktorat Jenderal Perikanan Tangkap. Dalam melaksanakan proses perizinan SIUP, SIPI dan SIKPI Direktorat Pelayanan Usaha Penangkapan Ikan KKP tidak memungut upah atau bayaran dari pengguna izin. Kondisi ini sangat baik karena Cavaluzzo (2002) dalam penelitiannya tentang kompetisi, tuntutan biaya pelayanan, dan performa pekerjaan pemerintah yang bertujuan menguji dampak kompetisi, tuntutan biaya pelayanan pada efisiensi dan kualitas pelayanan pemerintah menemukan bahwa tuntutan biaya pelayanan pada pemerintah tidaklah cukup untuk memotivasi peningkatan performa pekerjaan.

Perjanjian bilateral/Billateral Arrangement (BA) dengan negara asing dilakukan KKP dengan tiga negara yaitu RRC, Thailand dan Philipina. Keuntungan perizinan dengan lisensi memberikan keuntungan peningkatan nilai devisa dari pungutan perikanan kapal asing. Kerugiannya adalah menyebabkan armada nasional tidak berkembang, dominannya tenaga kerja asing serta pengurasan SDI terutama di wilayah perairan tempat beroperasinya kapal ikan asing. BA antara pemerintah RI dengan Philipina telah berakhir pada tanggal 3 Desember 2005 dan BA antara pemerintah RI dengan Thailand telah berakhir sejak tanggal 16 September 2006 dan dilanjutkan dalam bentuk joint venture, sewa atau impor kapal oleh PMA atau perusahaan swasta nasional yang menggunakan eks kapal lisensi (eks. Kapal Ikan berbendera Thailand) sesuai dengan ketentuan yang tertuang dalam Peraturan Menteri 17/MEN/ 2006. Perjanjian BA antara pemerintah RI dengan RRC berakhir pada Juli 2007. Berhentinya perjanjian Billateral Arrangement dengan ketiga negara tersebut menyebabkan menurunnya penerimaan pungutan perikanan dari kapal ikan asing (Direktorat Pelayanan Usaha Penangkapan Ikan).

Tabel 7 Tingkat kontribusi nilai PNBP KKP dari PPP dan PHP dan realisasi pencapaian.

\begin{tabular}{lcccc}
\hline Tahun & $\begin{array}{c}\text { Pemasukan } \\
\text { (Nilai PNBP) }\end{array}$ & $\begin{array}{c}\text { Tingkat kontribusi } \\
\text { PNBP KKP }\end{array}$ & \multicolumn{2}{c}{$\begin{array}{c}\text { Pengeluaran } \\
\text { (Realisasi Pencapaian) }\end{array}$} \\
\hline & Rp & $\%$ & Rp. & $\%$ \\
\hline 2005 & 272.220 .000 .000 & 94,22 & 6.678 .770 .010 & 99,29 \\
2006 & 198.148 .548 .096 & 92,02 & 6.422 .721 .000 & 98,25 \\
2007 & 114.244 .315 .062 & 84,86 & 5.507 .578 .000 & 88,82 \\
2008 & 77.402 .002 .423 & 74,29 & 4.610 .637 .000 & 97,58 \\
\hline Sumber : & \multicolumn{2}{l}{ Olahan data dan Direktorat Pelayanan Usaha Penangkapan Ikan - DKP (2009), Lampiran } \\
& LAKIP DKP dan Buku Data Potensi (2009), Produksi dan Ekspor Impor Kelautan dan Perikanan \\
& (2007) & & &
\end{tabular}




\section{Perspektif Pelanggan}

Pelanggan pada Direktorat Pelayanan Usaha Penangkapan Ikan adalah orang/institusi yang memiliki kepentingan untuk mendaftarkan izin usaha dan izin kapal ikan yang berukuran lebih dari 30 GT dan mesin lebih dari 90 DK. Dalam operasional Direktorat ini berusaha memenuhi kebutuhan para pengguna izin sesuai dengan peraturan Menteri Kelautan dan Perikanan nomor PER.05/MEN/2008 dan PER.12/ MEN/2009. Jumlah responden terdiri dari 21 pengguna izin yang terdiri dari pemilik usaha dan pengurus izin. Pada perspektif pelanggan diukur tanggapan responden terhadap 5 kelompok pertanyaan yang terdiri dari tangibility, reliability, responsiveness, assurance dan emphaty.

Nilai skor persepsi rata-rata pada kelompok tangibility lebih rendah dibandingkan skor harapan pelanggan. Kondisi ini menunjukkan bahwa pelayanan bidang tangibility belum memenuhi harapan responden. Akan tetapi tingkat kepuasan pada kelompok ini mencapai $96,66 \%$ dimana nilai persepsi hampir menyamai nilai harapan pelanggan. Akses untuk menuju kantor KKP yang terletak di Jl. Medan Merdeka Timur No.16 Jakarta Pusat dapat diakses dengan menggunakan angkutan umum kereta dan bus umum, sedangkan untuk mencapai lokasi kantor Direktorat Pelayanan Usaha Penangkapan Ikan yang terletak di lantai 9, disediakan lift dan tanggga yang cukup memadai. Pada ruang tunggu disediakan sofa dan tempat duduk untuk para pengurus izin. Air conditioner yang disediakan berfungsi dengan baik, sehingga pengurus izin merasa nyaman.

Nilai skor persepsi rata-rata pada kelompok reliability lebih rendah dibandingkan skor harapan pelanggan. Kondisi ini menunjukkan bahwa pelayanan bidang reliability belum memenuhi harapan responden. Tingkat kepuasan pada kelompok ini adalah $71,4 \%$. Nilai ini dianggap masih jauh dalam memenuhi harapan pelanggan. Ketidakpuasan reponden dalam kecepatan pelayanan penyelesaian pembuatan perpanjangan SIPI/SIKPI dikarenakan kapal yang sedang beroperasi harus kembali ke pelabuhan pangkalannya untuk melakukan cek fisik kapal. Pembayaran pungutan perikanan tidak dilakukan di Direktorat Pelayanan Usaha Penangkapan Ikan-KKP, tetapi pada bank persepsi yaitu Bank Mandiri. Proses pembayaran dapat diselesaikan dalam beberapa jam, akan tetapi kendalanya tidak semua Bank Mandiri dapat melakukan proses pembayaran pungutan.

Nilai skor persepsi rata-rata kelompok responsiveness lebih rendah dibandingkan skor harapan pelanggan. Kondisi ini menunjukkan bahwa pelayanan bidang responsiveness belum memenuhi harapan responden. Tingkat kepuasan pada kelompok ini adalah $80 \%$. Nilai ini mendekati harapan pelanggan. Bagian penerimaan pengajuan dilakukan di loket yang setiap harinya selalu ada yang bertugas menerima pengajuan. Direktorat Pelayanan Usaha Penangkapan Ikan-KKP segera memperbaiki dokumen jika terdapat kesalahan, tetapi apabila kesalahan dikarenakan kesalahan penulisan dari pelanggan, maka pengajuan proses perizinan harus diulang kembali.

Nilai skor persepsi rata-rata kelompok assurance lebih rendah dibandingkan skor harapan pelanggan. Kondisi ini menunjukkan bahwa pelayanan bidang assurance belum memenuhi harapan responden. Akan tetapi nilai persepsi mendekati nilai harapan pelanggan dengan tingkat kepuasan 91,95\%. Berdasarkan hasil wawancara dengan responden menyatakan bahwa perhitungan berdasarkan GT tidak mewakili sepenuhnya terhadap hasil tangkapan kapal, akan tetapi lebih mewakili besarnya ukuran kapal. Pelanggan membayar PPP dan PHP berdasarkan pada Surat Perintah Pembayaran (SPP) yang diterbitkan oleh Direktorat Pelayanan Usaha Penangkapan Ikan. Selanjutnya bukti pembayaran diserahkan kembali ke Direktorat Pelayanan Usaha Penangkapan Ikan sebagai salah satu syarat kelengkapan dokumen. Beberapa responden belum mengetahui bahwa simulasi perhitungan telah disediakan melalui web perizinan, sedangkan responden yang lain telah mengetahui bagaimana cara perhitungan pungutan PPP dan PHP.

Nilai skor persepsi rata-rata kelompok emphaty lebih rendah dibandingkan skor harapan pelanggan. Kondisi ini menunjukkan bahwa pelayanan bidang emphaty belum memenuhi harapan responden. Tingkat kepuasan pada kelompok emphaty termasuk rendah yaitu $56,97 \%$. Beberapa hal dirasakan tidak puas oleh responden. Pelanggan menyatakan tidak puas dikarenakan belum adanya kejelasan lamanya proses pada tiap tahap. Kemudahan komunikasi dan hubungan secara langsung dengan staf Direktorat Pelayanan Usaha Penangkapan Ikan dirasakan tidak puas oleh beberapa responden tentang tahapan penyelesaian dokumen perizinan, sedangkan responden yang menyatakan puas dan cukup puas dalam melakukan komunikasi dan hubungan secara langsung berpendapat bahwa informasi proses pengajuan dokumen dilakukan dengan baik oleh Direktorat Pelayanan Usaha Penangkapan Ikan. Responden yang menyatakan sangat tidak puas dan tidak puas pada indikator kemudahan mendapatkan informasi melalui media memberikan argumen bahwa mereka tidak pernah 
mendapatkan informasi penyelesaian dokumen perizinan melalui telepon atau media lainnya. Mereka harus datang ke Direktorat Pelayanan Usaha Penangkapan Ikan beberapa hari sekali untuk mengetahui apakah proses perizinan yang diajukan telah selesai atau belum. Responden yang menyatakan puas dengan kemudahan mendapatkan informasi melalui media karena mereka sangat aktif menanyakan melalui telepon ke Direktorat Pelayanan Usaha Penangkapan lkan.

\section{Analisis Hasil Kinerja Keseluruhan}

Analisis hasil kinerja keseluruhan mencakup perspektif pembelajaran dan pertumbuhan, perspektif proses bisnis internal, perspektif finansial dan perpektif pelanggan. Hasil analisis kinerja secara keseluruhan menunjukkan nilai 3,34 atau cukup. Kondisi ini menunjukkan bahwa Direktorat Pelayanan Usaha Penangkapan Ikan perlu suatu strategi dengan melakukan inisiatif-inisiatif agar target tercapai dan visi dan misi dari Direktorat Pelayanan Usaha Penangkapan Ikan dapat diwujudkan.

Tabel 8 Tanggapan responden terhadap tampilan fisik (tangibility)

\begin{tabular}{|c|c|c|c|c|c|c|}
\hline \multirow{2}{*}{ No } & \multirow{2}{*}{ Pertanyaan } & \multicolumn{5}{|c|}{ Jawaban } \\
\hline & & 1 & 2 & 3 & 4 & 5 \\
\hline \multirow[t]{2}{*}{1} & \multirow{2}{*}{$\begin{array}{l}\text { Kemudahan dalam menjangkau letak/lokasi } \\
\text { kantor dan ketersediaan tempat parkir serta } \\
\text { pengamanan lingkungan kantor }\end{array}$} & 0 & 0 & 0 & 12 & 9 \\
\hline & & $0 \%$ & $0 \%$ & $0 \%$ & $57,1 \%$ & $42,9 \%$ \\
\hline \multirow[t]{2}{*}{2} & \multirow{2}{*}{$\begin{array}{l}\text { Penampilan kantor dan kenyamanan serta } \\
\text { kebersihan ruang tunggu }\end{array}$} & 0 & 0 & 3 & 11 & 7 \\
\hline & & $0 \%$ & $0 \%$ & $14,3 \%$ & $52,4 \%$ & $33,3 \%$ \\
\hline \multirow[t]{2}{*}{3} & \multirow{2}{*}{$\begin{array}{l}\text { ketersediaan fasilitas kantor dan informasi } \\
\text { pelayanan di ruang tunggu }\end{array}$} & 0 & 0 & 5 & 16 & 0 \\
\hline & & $0 \%$ & $0 \%$ & $23,8 \%$ & $76,2 \%$ & $0 \%$ \\
\hline
\end{tabular}

Tabel 9 Analisis tingkat kepuasan pelanggan pada kelompok tangibility

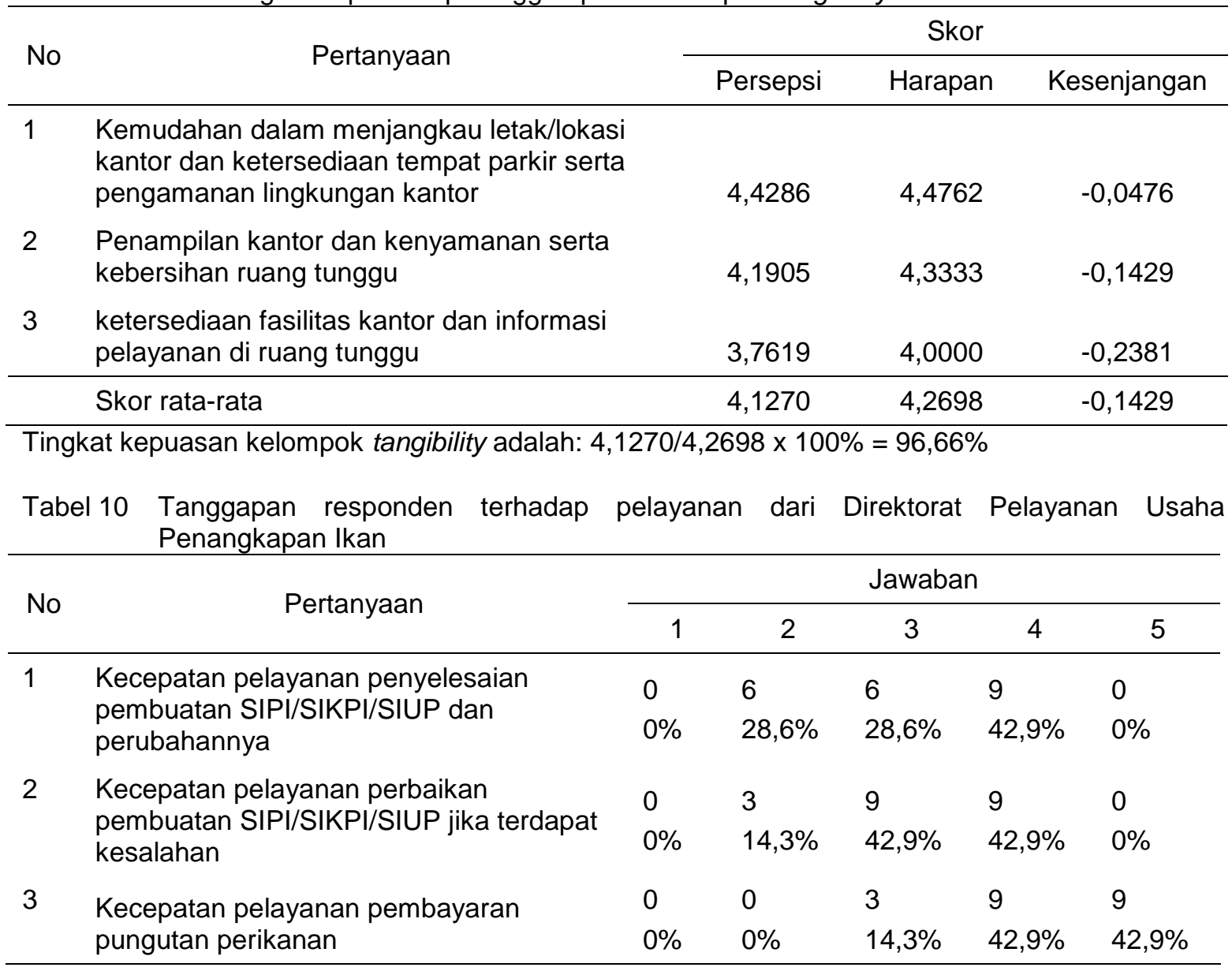


Tabel 11 Analisis tingkat kepuasan pada kelompok reliability

\begin{tabular}{|c|c|c|c|c|c|c|}
\hline \multirow{2}{*}{ No } & \multirow{2}{*}{ Pertanyaan } & \multicolumn{5}{|c|}{ Skor } \\
\hline & & \multicolumn{2}{|c|}{ Persepsi } & Harapan & \multicolumn{2}{|c|}{ Kesenjangar } \\
\hline 1 & $\begin{array}{l}\text { Kecepatan pelayanan penyelesaian } \\
\text { pembuatan SIPI/SIKPI/SIUP dan } \\
\text { perubahannya }\end{array}$ & & 429 & 5,0000 & & 8571 \\
\hline 2 & $\begin{array}{l}\text { Kecepatan pelayanan perbaikan pembuatan } \\
\text { SIPI/SIKPI/SIUP jika terdapat kesalahan }\end{array}$ & & 857 & 5,0000 & & 7143 \\
\hline \multirow[t]{2}{*}{3} & $\begin{array}{l}\text { Kecepatan pelayanan pembayaran pungutan } \\
\text { perikanan }\end{array}$ & & 857 & 5,0000 & & 7143 \\
\hline & Skor rata-rata & & 714 & 5,0000 & & 4286 \\
\hline \multicolumn{7}{|c|}{$\begin{array}{l}\text { Tabel } 12 \text { Tanggapan responden terhadap ketanggapan } \\
\text { Ikan dalam membantu memberikan pelayanan }\end{array}$} \\
\hline \multirow{2}{*}{ No } & \multirow{2}{*}{ Pertanyaan } & \multicolumn{5}{|c|}{ Jawaban } \\
\hline & & 1 & 2 & 3 & 4 & 5 \\
\hline \multirow{2}{*}{1} & \multirow{2}{*}{$\begin{array}{l}\text { Respon KKP dalam menanggapi pengajuan } \\
\text { pembuatan SIPI/SIKPI/IUP }\end{array}$} & 0 & 0 & 15 & 6 & 0 \\
\hline & & $0 \%$ & $0 \%$ & $71,4 \%$ & $28,6 \%$ & $0 \%$ \\
\hline \multirow{2}{*}{2} & \multirow{2}{*}{$\begin{array}{l}\text { Respon KKP dalam menanggapi kesalahan } \\
\text { pembuatan SIPI/SIKPI/SIUP dan } \\
\text { perubahannya }\end{array}$} & 0 & 0 & 15 & 6 & 0 \\
\hline & & $0 \%$ & $0 \%$ & $71,4 \%$ & $28,6 \%$ & $0 \%$ \\
\hline
\end{tabular}

Tabel 13 Analisis tingkat kepuasan pada kelompok responsiveness

\begin{tabular}{|c|c|c|c|c|c|c|}
\hline \multirow{2}{*}{ No } & \multirow{2}{*}{ Pertanyaan } & \multicolumn{5}{|c|}{ Skor } \\
\hline & & \multicolumn{2}{|c|}{ Persepsi } & Harapan & \multicolumn{2}{|c|}{ Kesenjangan } \\
\hline 1 & $\begin{array}{l}\text { Respon KKP dalam menanggapi pengajuan } \\
\text { pembuatan SIPI/SIKPI/IUP }\end{array}$ & \multicolumn{2}{|c|}{3,2857} & 4,0000 & \multicolumn{2}{|c|}{$-0,7143$} \\
\hline \multirow[t]{2}{*}{2} & $\begin{array}{l}\text { Respon KKP dalam menanggapi kesalahan } \\
\text { pembuatan SIPI/SIKPI/SIUP dan } \\
\text { perubahannya }\end{array}$ & \multicolumn{2}{|c|}{3,2857} & 4,0000 & \multicolumn{2}{|c|}{$-0,7143$} \\
\hline & Skor rata-rata & \multicolumn{2}{|c|}{3,2857} & 4,0000 & \multicolumn{2}{|c|}{$-0,7143$} \\
\hline \multicolumn{7}{|c|}{$\begin{array}{c}\text { Tabel } 14 \text { Tanggapan responden terhadap jaminan mengenai kemampuan, kesopanan, keahlian, } \\
\text { dan sifat dapat dipercaya dari karyawan Direktorat Pelayanan Usaha Penangkapan Ikan }\end{array}$} \\
\hline \multirow{2}{*}{ No } & \multirow{2}{*}{ Pertanyaan } & \multicolumn{5}{|c|}{ Jawaban } \\
\hline & & 1 & 2 & 3 & 4 & 5 \\
\hline 1 & $\begin{array}{l}\text { Keramahan staf dalam memberikan } \\
\text { pelayanan }\end{array}$ & $\begin{array}{l}0 \\
0 \%\end{array}$ & $\begin{array}{l}0 \\
0 \%\end{array}$ & $\begin{array}{l}9 \\
42,9 \%\end{array}$ & $\begin{array}{l}12 \\
57,1 \%\end{array}$ & $\begin{array}{l}0 \\
0 \%\end{array}$ \\
\hline 2 & $\begin{array}{l}\text { Penampilan fisik, kesopanan, dan } \\
\text { kebersihan karyawan yang memberikan } \\
\text { pelayanan }\end{array}$ & $\begin{array}{l}0 \\
0 \%\end{array}$ & $\begin{array}{l}0 \\
0 \%\end{array}$ & $\begin{array}{l}0 \\
0 \%\end{array}$ & $\begin{array}{l}21 \\
100 \%\end{array}$ & $\begin{array}{l}0 \\
0 \%\end{array}$ \\
\hline 3 & $\begin{array}{l}\text { Pengetahuan dan ketrampilan staf yang } \\
\text { memberikan pelayanan }\end{array}$ & $\begin{array}{l}0 \\
0 \%\end{array}$ & $\begin{array}{l}0 \\
0 \%\end{array}$ & $\begin{array}{l}0 \\
0 \%\end{array}$ & $\begin{array}{l}21 \\
100 \%\end{array}$ & $\begin{array}{l}0 \\
0 \%\end{array}$ \\
\hline 4 & Jaminan ketepatan perhitungan pungutan & $\begin{array}{l}0 \\
0 \%\end{array}$ & $\begin{array}{l}0 \\
0 \%\end{array}$ & $\begin{array}{l}18 \\
85,7 \%\end{array}$ & $\begin{array}{l}3 \\
14,3 \%\end{array}$ & $\begin{array}{l}0 \\
0 \%\end{array}$ \\
\hline
\end{tabular}


Tabel 15 Analisis tingkat kepuasan pada kelompok assurance

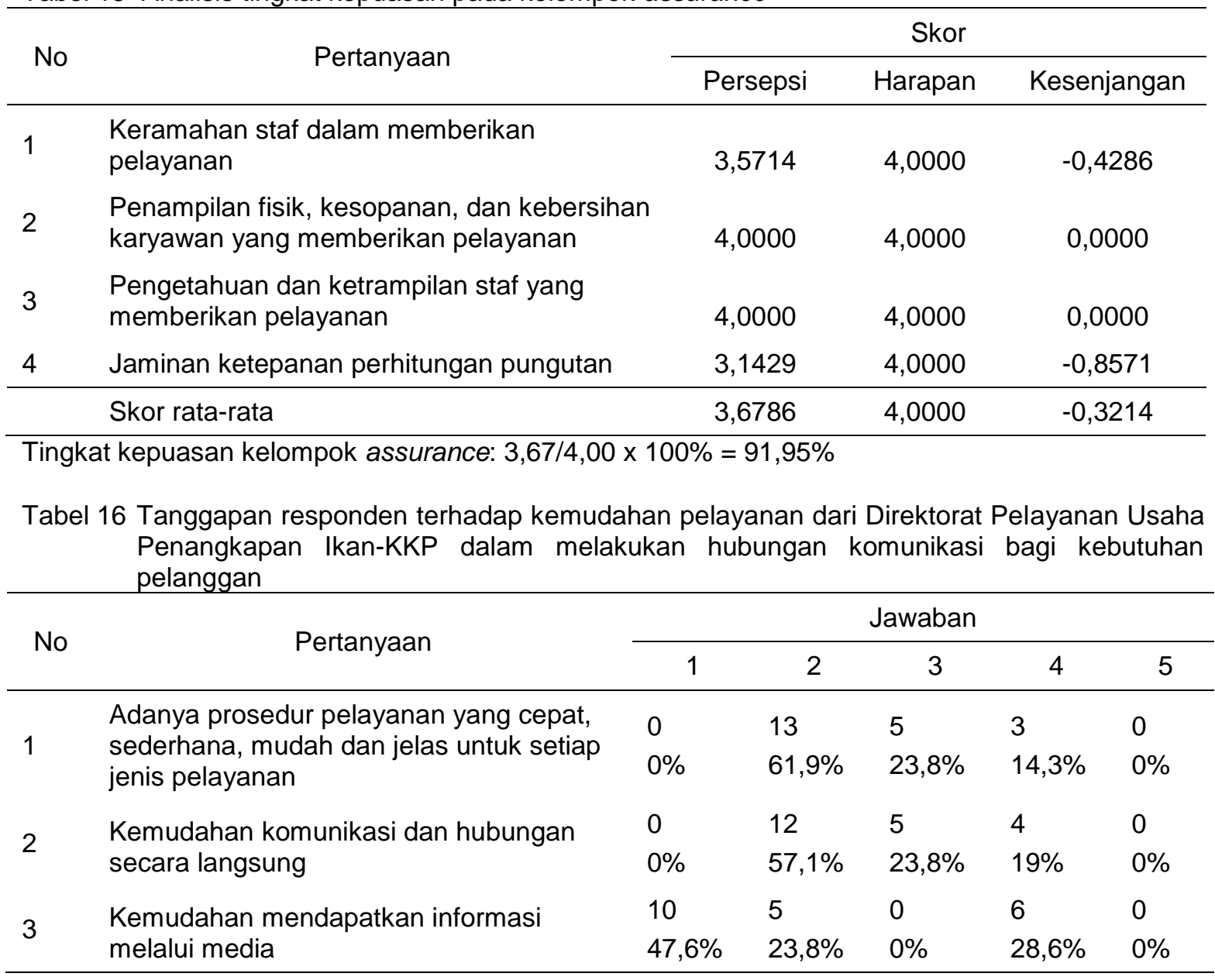

Tabel 17 Analisis tingkat kepuasan pada kelompok emphaty

\begin{tabular}{|c|c|c|c|c|}
\hline \multirow{2}{*}{ No } & \multirow{2}{*}{ Pertanyaan } & \multicolumn{3}{|c|}{ Skor } \\
\hline & & Persepsi & Harapan & Kesenjangan \\
\hline 1 & $\begin{array}{l}\text { Adanya prosedur pelayanan yang cepat, } \\
\text { sederhana, mudah dan jelas untuk setiap jenis } \\
\text { pelayanan }\end{array}$ & 2,5238 & 4,7143 & $-2,1905$ \\
\hline 2 & $\begin{array}{l}\text { Kemudahan komunikasi dan hubungan secara } \\
\text { langsung }\end{array}$ & 2,6190 & 4,0000 & $-1,3810$ \\
\hline 3 & $\begin{array}{l}\text { Kemudahan mendapatkan informasi melalui } \\
\text { media }\end{array}$ & 2,0952 & 4,0000 & $-1,9048$ \\
\hline & Skor rata-rata & 2,4127 & 4,2381 & $-1,8254$ \\
\hline
\end{tabular}

Tingkat kepuasan kelompok emphaty: 2,41/4,23 x 100\% = 56,97\% 
Tabel 18 Hasil pengukuran kinerja secara keseluruhan.

\begin{tabular}{|c|c|c|c|c|c|}
\hline No & Aspek yang diukur & $\begin{array}{c}\text { Hasil } \\
\text { Pengukuran }\end{array}$ & $\begin{array}{l}\text { Skor } \\
(1-5)\end{array}$ & $\begin{array}{c}\text { Bobot } \\
(\%)\end{array}$ & Skor x Bobot \\
\hline \multirow[t]{5}{*}{1} & $\begin{array}{l}\text { Perspektif Pembelajaran dan } \\
\text { Pertumbuhan }\end{array}$ & & & & \\
\hline & 1. Kompetensi staf & Baik & 4 & 7 & 0,28 \\
\hline & 2. Partisipasi staf & Baik & 4 & 7 & 0,28 \\
\hline & $\begin{array}{l}\text { 3. Riset atau pengembangan proses } \\
\text { perizinan usaha perikanan }\end{array}$ & Cukup & 3 & 6 & 0,18 \\
\hline & Skor Perspektif I & & 11 & & \\
\hline \multirow[t]{5}{*}{2} & Perspektif Proses Bisnis internal & & & & \\
\hline & 1. Tahap inovasi & Baik & 4 & 10 & 0,4 \\
\hline & 2. Tahap operasi/produksi & Baik & 4 & 10 & 0,4 \\
\hline & 3. Tahap pelayanan purna izin & Baik & 4 & 10 & 0,4 \\
\hline & Skor Perspektif II & & 12 & & \\
\hline \multirow[t]{4}{*}{3} & Perspektif Finansial & & & & \\
\hline & 1. Tingkat kontribusi PNBP KKP & Cukup & 3 & 10 & 0,3 \\
\hline & 2. Tingkat penyerapan dana & Sangat baik & 5 & 10 & 0,5 \\
\hline & Skor Perspektif III & & 7 & & \\
\hline \multirow[t]{4}{*}{4} & Perspektif Pelanggan & & & & \\
\hline & 1. Tingkat kepuasan pelanggan & Kurang & 2 & 30 & 0,6 \\
\hline & Skor Perspektif IV & & 2 & & \\
\hline & TOTAL & & 32 & & 3,34 \\
\hline
\end{tabular}

\section{KESIMPULAN DAN SARAN}

\section{Kesimpulan}

Hasil kinerja Direktorat Pelayanan Usaha Penangkapan Ikan-KKP dengan menggunakan pendekatan balanced scorecard menunjukkan nilai 3,34 atau cukup.

\section{Saran}

Direktorat Pelayanan Usaha Penangkapan Ikan sebaiknya mengaplikasikan strategi dengan pendekatan balanced scorecard untuk organisasi non profit dimana pendekatan balanced scorecard menilai kinerja tidak hanya berdasarkan perspektif finansial saja, tetapi juga perspektif pertumbuhan dan pembelajaran, perspektif proses bisnis internal dan terutama pada perspektif pelanggan.

\section{DAFTAR PUSTAKA}

Gaspersz V. 2002. Sistem Manajemen Kinerja Terintegrasi: Balanced Scorecard de- ngan Six Sigma untuk Organisasi Bisnis dan Pemerintah. Jakarta: Gramedia Pustaka Utama. 325 halaman.

Gil D.G, C.I. Malvido, J.C.S. Regueiro \& M.M.V. Lafuente. 1996. The Spanish case regarding fishing regulation. Marine Policy Journal Vol.20 No.3. pp 249-259.

Kaplan R.S \& D.P. Norton. 2000. Balanced Scorecard: Menerapkan Strategi menjadi Aksi. Jakarta: Terjemahan. Erlangga. 288 halaman

Karahalios H, Z.L. Yang, V.Williams \& J. Wang. 2010. A proposed System if Hierarchical Scorecards to Assess the Implementation of Maritime Regulations. Safety Science Journal (article in press).

Koellner T, J. Sell, M. Gahwiler \& R.W. Scholz. 2008. Assessment of The Management of Organizations Supplying Ecosystem Services from Tropical Forest. Global Enviromental Change Journal 18. p 746757. 
Kusyanto D., M.F.A. Sondita, D.R.Monintja, J.Haluan \& Soepanto. 2006. Kebijakan dan Pelayanan Pelabuhan Perikanan Samudera terhadap Daya Saing Industri Perikanan pada Perdagangan Global di Pelabuhan Perikanan Samudera Jakarta. Jurnal Penelitian Perikanan Volume 9 No.1, Juni 2006. Fakultas Perikanan Universitas Brawijaya Malang. Malang. 121 halaman.

Moullin M. 2002. Delivering Excellence in Health and Social Care. Open University Press. Milton Keynes.

2009. Public Sector Scorecard. Nursing Management Journal Vol 16 No 5. pp 26-31.

Mulyana R. 2007. Perizinan sebagai Alat dalam Pengelolaan Perikanan. Jakarta: Pusat Riset Perikanan Tangkap. Sistem Alternatif Manajemen Sumber daya Kelautan dan Perikanan. Halaman 7-20

Murdiyanto B. 2004. Pelabuhan Perikanan. Fungsi, Fasilitas, Panduan Operasional, Antrian Kapal. Jurusan Pemanfaatan
Sumber daya Perikanan. Fakultas Perikanan dan Ilmu Kelautan. IPB. Bogor

Niven P.R. 2003. Balanced Scorecard step by step for government and not-for-profit agencies. Canada : John Wiley \& Sons, Inc., Hoboken New Jersey. 305 pages.

On Wing B.W., L. Guo, W. Li \& D. Yang. 2007. Reducing Conflict in Balanced Scorecard Evaluations. Accounting, Organizations and Society Journal 32. pp 363-377.

Wu H.Y, Y.K. Lin \& C.H.Chang. 2011. Performance Evaluation of Extension Education Centers in Universities Based on The Balanced Scorecard. Evaluation and Program Planning Journal. Volume 34.p 37-50.

Young M.D. 1999. The Design of Fishing Right System-The NSW Experience. Ecological Economics Journal : 305-316 p.

Yuniarta S. 2009. Strategi Pengembangan Kinerja Perizinan Usaha Penangkapan Ikan [Thesis]. Bogor: Program Pascasarjana, Institut Pertanian Bogor. 